\title{
Comparative qualitative profile of various extracellular enzymes produced by two indigenous fungus Lentinus cladopus and Pleurotus pulmonarius
}

\author{
Deepak K Rahi ${ }^{*}$, Shabnam Thakur $^{2}$ and Deepika Malik ${ }^{3}$ \\ ${ }^{1}$ Department of Microbiology, Panjab University, Chandigarh-160014, India \\ ${ }^{2}$ Department of Microbiology, Panjab University, Chandigarh-160014, India \\ ${ }^{3}$ Department of Microbiology, Panjab University, Chandigarh-160014, India \\ *Corresponding Author: deepakrahi10@ rediffmail.com
}

Available online at: www.isroset.org

Received: 21/May/2018, Revised: 30/May/2018, Accepted: 17/Jun/2018, Online: 30/Jun/ 2018

\begin{abstract}
White rot fungi are well known prominent and efficient producers of various extra-cellular enzymes that play an essential role in various industries including food, paper, textile, medicine, etc. Therefore, the two important white rot species of Lentinus cladopus and Pleurotus pulmonarius were screened for the qualitative profile of various enzymes on solid medium. The result obtained revealed the remarkable presence of different extracellular enzymes including cellulase, mannanase, xylanase, pectinase, amylase, lipase and protease by both the fungi. However Pleurotus pulmonarius was found to be more efficient in producing almost each screened enzymes in comparison to Lentinus cladopus.
\end{abstract}

Keywords: Basidiomycete, White rot fungi, Enzyme profile, Qualitative production

\section{INTRODUCTION}

White rot fungi, belonging to class basidiomycetes, are known to produce various extra cellular enzymes that play essential role in various industries including food, paper, textile and medicine. Research has been done on evaluating various enzymes of different basidiomycetes, however the white rot fungi group has not been explored uniformly for their entire enzymatic potential. The literature survey reveals the work only on few commercially established species like Phaenerochaete chrysosporium (Srinivasan et al., 1995, Peng et al., 2008, Jhadav et al., 2009), Schizophyllum communae (De vries et al., 1986) and few species of Pleurotus (Palmieri et al., 1997, Marques de Souza and Peralta, 2003, Salis et al., 2009). White rot fungi are effective organism in lignocelluloses degradation (Reddy, 1995). These fungi are known to produce lignocellulolytic enzymes that act cooperatively to degrade the component of lignocelluloses (Jung et al., 2002, Sanchez, 2009). However, these have been explored very less for potential of other enzymes. These enzymes have many applications in several areas such as pectinase have role in dairy industry and fruit juice clarification, lipase have applications in degradation of particulate organic matter (Whiteley et al.,2003). Proteases have large variety of applications in food industry, related to the nutritional and functional value of the products. These include improving the digestibility and sensory quality of food, as well as provide health benefits by reducing allergenic compounds (Tavano, 2013). They are mainly used for food processing. Therefore, in the present study, these two edible species belonging to white rot fungi i.e. Lentinus cladopus and Pleurotus pulmonarius have been screened for other enzymes also apart from ligninases, cellulases and hemicellulases. A comparative analysis was made on the basis of their qualitative performances.

\section{MATERIALS AND METHODS}

Materials

All the chemicals used were from Sigma and Himedia.

\section{Procurement of fungus}

Pure culture of both fungal species i.e. Lentinus cladopus and Pleurotus pulmonarius was obtained from mycology laboratory, Department of Microbiology, Panjab University, Chandigarh and maintained on potato dextrose agar (PDA) and preserved at $4{ }^{\circ} \mathrm{C}$.

\section{Qualitative screening of enzymes}

The qualitative enzymatic screening of the test fungi was determined as per Hankin and Anagnostakis, 1975 by supplementing the respective enzyme substrate in the production medium. The test fungi Lentinus cladopus and Pleurotus pulmonarius were screened for the presence of cellulases, mannanases, xylanases, laccases, pectinases, amylases, lipases and proteases on potato dextrose agar by supplementing the medium separately with $1 \%$ of respective substrates i.e. carboxymethyl cellulose, locust bean gum, xylan, guiacol, pectin, starch, tributyrin and casein 
respectively. Three replicates were maintained for each set of observation. On solidification, the plates were spot inoculated at the center with $5 \mathrm{~mm}$ mycelium disc of the test fungus and incubated at $28 \pm 1^{\circ} \mathrm{C}$ for 7 days. The respective enzyme activities were evaluated by observing and measuring the zones of clearance, if any formed, by flooding the plates with visualizing reagent for 15 minutes i.e congo red for cellulose and mannanase, iodine solution for xylanase and amylase, coomassie brilliant blue for protease, while laccase activity was assessed by observing the dark brown colored zones around fungal colony.

\section{RESULTS}

The qualitative screening performed for different enzyme producing potential of the test fungi (Lentinus cladopus and Pleurotus pulmonarius) revealed a remarkable presence of more and less all the enzymes which were screened.

Table 1: The diametric size of zone of clearance of various enzymes screened from Lentinus cladopus and Pleurotus pulmonarius.

\begin{tabular}{|c|c|c|c|c|c|c|c|c|}
\hline Enzymes & $\begin{array}{l}\mathbf{C M} \\
\mathbf{C}\end{array}$ & $\begin{array}{l}\text { Lipa } \\
\text { ses }\end{array}$ & $\begin{array}{l}\text { La } \\
\text { cca } \\
\text { se }\end{array}$ & $\begin{array}{l}\text { Xyla } \\
\text { nase } \\
\text { s }\end{array}$ & $\begin{array}{l}\text { Man } \\
\text { nana } \\
\text { se }\end{array}$ & $\begin{array}{l}\text { Pro } \\
\text { teas } \\
\text { e }\end{array}$ & $\begin{array}{l}\text { Pect } \\
\text { inas } \\
\text { e }\end{array}$ & $\begin{array}{l}\text { Amy } \\
\text { lase }\end{array}$ \\
\hline $\begin{array}{l}\text { Lentinus } \\
\text { cladopus } \\
\text { Pleurotus } \\
\text { pulmonar } \\
\text { ius }\end{array}$ & $\begin{array}{l}2.4 \\
\pm .1 \\
\mathrm{~cm} \\
\\
2.1 \\
\pm .1 \\
\mathrm{~cm}\end{array}$ & $\begin{array}{l}1.85 \\
\pm .1 \mathrm{c} \\
\mathrm{m} \\
\\
1.75 \\
\pm .05 \\
\mathrm{~cm}\end{array}$ & $\begin{array}{l}4.9 \\
\pm .3 \\
\mathrm{~cm} \\
\\
5.1 \\
\pm .2 \\
\mathrm{~cm}\end{array}$ & $\begin{array}{l}3.05 \\
\pm .05 \\
\mathrm{~cm} \\
5.6 \pm . \\
1 \mathrm{~cm}\end{array}$ & $\begin{array}{l}4.2 \pm . \\
1 \mathrm{~cm} \\
4.5 \pm . \\
05 \\
\mathrm{~cm}\end{array}$ & $\begin{array}{l}3.1 \\
\pm .1 \\
\mathrm{~cm} \\
\\
3.4 \\
\pm .2 \\
\mathrm{~cm}\end{array}$ & $\begin{array}{l}1.4 \pm \\
.1 \\
\mathrm{~cm} \\
1.9 \pm \\
.05 \mathrm{c} \\
\mathrm{m}\end{array}$ & $\begin{array}{l}1.65 \\
\pm .05 \\
\mathrm{~cm} \\
\\
1.5 \pm . \\
1 \mathrm{~cm}\end{array}$ \\
\hline
\end{tabular}

Values are mean SD of three observations.

The species of Lentinus cladopus was found capable of producing laccase enzyme maximally, followed by mannanase and protease (Fig 1). Whereas, Pleurotus pulmonarius was more efficient in producing xylanase, followed by laccase and mannanase (Fig 2).Overall the species of Pleurotus pulmonarius was found to be more efficient in producing almost each screened enzymes as revealed by broader zone of hydrolysis.
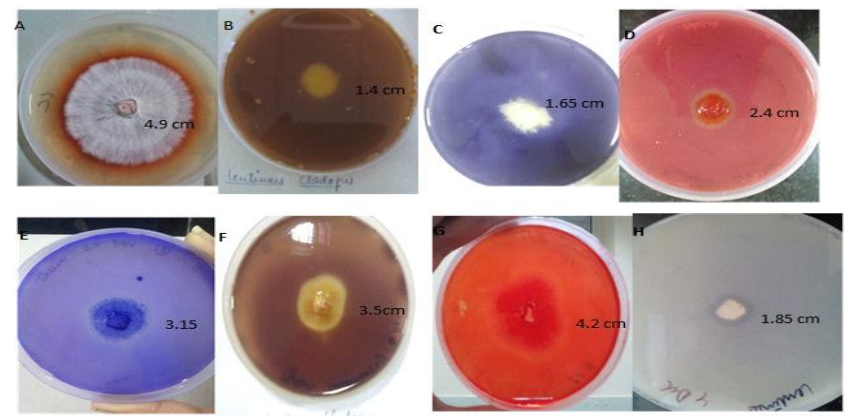

Figure 1: Qualitative screening of Lentinus cladopus for production of (A) Laccase; (B) Pectinase; (C) Amylase; (D) Cellulase; (E) Protease; (F) Xylanase; (G) Mannanase; and (H) Lipase on solid media supplemented with their respective substrates.
- Production media : Potato dextrose agar

- Substrate concentration: $1 \%$ of medium volume.

- Substrate used: Laccase (guiacol); Pectinase (pectin); Amylase (starch); Cellulase (carboxymethyl cellulose); Protease (casein); Xylanase (xylan); Mannanase (locust bean gum); Lipase (tributyrin).

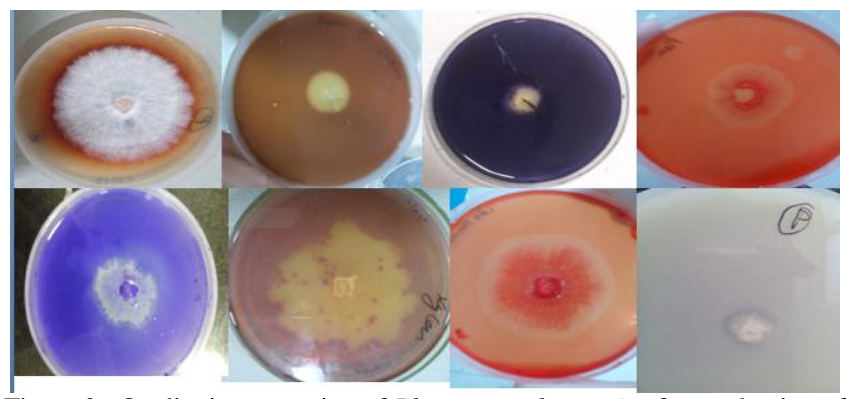

Figure 2: Qualitative screening of Pleurotus pulmonarius for production of (A) Laccase; (B) Pectinase; (C) Amylase; (D) Cellulase; (E) Protease; (F) Xylanase; (G) Mannanase; and (H) Lipase on solid media supplemented with their respective substrates.

- Production media : Potato dextrose agar

- Substrate concentration: $1 \%$ of medium volume.

- Substrate used: Laccase (guiacol); Pectinase (pectin); Amylase (starch); Cellulase (carboxymethyl cellulose); Protease (casein); Xylanase (xylan); Mannanase (locust bean gum); Lipase (tributyrin).

\section{CONCLUSION}

A number of microorganisms have been reported to produce various lignino- cellulolytic enzymes. But the white rot fungi are known to produce the most desirable qualities. Screening of qualitative enzymatic profile of important white rot fungi species i.e. Lentinus cladopus and Pleurotus pulmonarius showed their potential of producing other enzymes as well along with lignocellulytic enzymes. After determining quantitative studies, the enzyme activities can be enhanced and used accordingly for respective applications.

\section{ACKNOWLEDGEMENT}

Authors are thankful to Panjab University, Chandigarh, India for providing the research grant and necessary laboratory facilities to carry out the present work.

\section{REFERENCES}

[1]. C. Srinivasan, T.M. Dsouza, K. Boominathan, C. A. Reddy, "Demonstration of Laccase in the White rot Basidiomycete Phanerochaete chrysosporium BKM-F1767", Applied and Environmental Microbiology, Vol.61, Issue.12, pp.42744277, 1995.

[2]. D. Peng, G. X. Xie, G. M. Zeng, Y. N. Chen, F. R. Chen, S. Hu, $\mathrm{Z}$. $\mathrm{Yu}$, "Research and application of producing laccase by 
Phanerochaete chrysosporium in solid-state fermentation system”, PubMed, Vol.29, Issue.12, pp.3568-3573, 2008.

[3]. A. Jhadav, K. K. Vamsi, Y. Khairnar, A. Boraste, N. Gupta, S. Trivedi, P. Patil, G. Gupta, M. Gupta, A. K. Mujapara, B. Joshi, "Optimization of production and partial purification of laccase by Phanerochaete chrysosporium using submerged fermentation", International Journal of Microbiology Research, Vol.1, Issue.2, pp.9, 2009.

[4]. O. M. De Vries, W. H. Kooistra, J. G. Wessels, "Formation of an extracellular laccase by a Schizophyllum commune dikaryon", Microbiology, Vol.132, Issue.10, pp. 2817-2826, 1986.

[5]. G. Palmieri, P. Giardina, C. Bianco, A. Scaloni, A. Capasso, G. Sannia, "A novel white laccase from Pleurotus ostreatus", Journal of biological chemistry, Vol.272, Issue.50, pp. 3130131307, 1997.

[6]. C. G. Marques de Souza, R. M. Peralta, "Purification and characterization of the main laccase produced by the white rot fungus Pleurotus pulmonarius on wheat bran solid state medium", Journal of basic microbiology,Vol.43, Issue.4, pp. 278 -286, 2003.

[7]. A. Salis, M. Pisano, M. Monduzzi, V. Solinas, E. Sanjust, "Laccase from Pleurotus sajor-caju on functionalised SBA-15 mesoporous silica: Immobilisation and use for the oxidation of phenolic compounds", Journal of Molecular Catalysis B: Enzymatic, Vol.58, Issue.1, pp. 175-180, 2009.

[8]. L. Hankin, S. L. Anagnostakis, "The use of solid media for detection of enzyme production by fungi", Mycologia, Vol.1, pp. 597-607, 1975.

[9]. C.A. Reddy, "The potential for white-rot fungi in the treatment of pollutants", Current Opinion in Biotechnology, Vol.6, pp. 320328, 1995.

[10]. C. Sanchez, "Lignocellulosic residues: Biodegradation and bioconversion by fungi", Biotechnology Advances, Vol.27, pp. 185194, 2009.

[11]. H. Jung, F. Xu, K. Li, "Purification and characterization of laccase from wood-degrading fungus Trichophyton rubrum LKY7", Enzyme and Microbial Technology, Vol.30, pp. 161168, 2002.

[12]. C. G. Whiteley, J. E. Burgess, X. Melamane, B. Pletschke, P. D. Rose, "The enzymology of sludge solubilisation utilizing sulphatereducing systems: the properties of lipases", Water research, Vol.37, Issue.2, pp. 289-296, 2003.

[13]. O. L. Tavano, "Protein hydrolysis using proteases: An important tool for food biotechnology", Journal of Molecular Catalysis B: Enzymatic, Vol.90, pp. 1-11, 2013. 